\title{
PEMBUATAN DAN KARAKTERISASI MEMBRAN POLIMETILMETAKRILAT (PMMA) - BENTONIT UNTUK MEMISAHKAN MALTOSA DAN PATI
}

\section{(SYNTHESIS AND CHARACTERIZATION OF POLYMETHYLMETHACRYLATE (PMMA) - BENTONITE MEMBRANE FOR MALTOSE AND STARCH SEPARATION)}

\author{
Karim Abdullah ${ }^{1}$ dan Handajaya Rusli ${ }^{2}$ \\ ${ }^{1)}$ Baristan Industri Bandar Lampung \\ Jl. ByPass Soekarno Hatta Km 1 Bandar Lampung \\ ${ }^{2)}$ Kelompok Keilmuan Kimia Analitik, Institut Teknologi Bandung \\ Jl. Ganeca No.10 Bandung \\ E-mail : karim.abdullah@yahoo.com
}

Received : 8 Juli 2015; revised : 15 juli 2015; accepted : 22 Juli 2015

\begin{abstract}
ABSTRAK
Maltosa adalah salah satu senyawa turunan pati yang banyak digunakan sebagai pemanis untuk menggantikan sukrosa. Hidrolisis pati untuk menghasilkan maltosa dapat dilakukan dengan menggunakan reaktor kontinu yang menggunakan membran untuk memisahkan pati dan maltosa yang telah terbentuk. Pada penelitian ini, telah berhasil dibuat membran PMMA-Bentonit dengan kadar PMMA $14 \%(\mathrm{~m} / \mathrm{m})$ dalam pelarut N,Ndimetilformamida, dan perbandingan massa antara PMMA: bentonit adalah 3:1. Membran yang dihasilkan mampu memisahkan pati dengan persen rejeksi bervariasi antara $40 \%$ sampai dengan $70 \%$ dan melewatkan maltosa dengan persen rejeksi kurang dari $5 \%$. Proses pemisahan terjadi karena adanya pori pada membran. Hal ini didukung oleh foto SEM penampang melintang membran.
\end{abstract}

Kata kunci : Membran, Pati, Maltosa, PMMA, Bentonit

\begin{abstract}
Maltose is one of starch derivative compounds that used as sweetener to substitute sucrose. Hydrolysis of starch to produce maltose can be conducted by using a continuous reactor. In this experiment, PMMA-bentonite membranes has been synthesized successfully. Under PMMA concentration of $14 \%$ (w/w) in $\mathrm{N}, \mathrm{N}$-dimethylformamide solvent and ratio between PMMA:bentonite of 3:1 by mass. The result shows that the membrane can separate the starch from maltose with the variation percent rejection between $40 \%$ until $70 \%$ and less than $5 \%$ respectively. Separation process occurred because of membrane pores existence. This conclusion is proven by cross-section SEM images of the membrane.
\end{abstract}

Keywords : Membrane, Starch, Maltose, PMMA, Bentonite

\section{PENDAHULUAN}

Salah satu senyawa turunan pati yang banyak digunakan oleh industri adalah maltosa (suatu senyawa disakarida yang terbentuk dari dua glukosa). Maltosa dapat digunakan sebagai pemanis dan bahan baku pembuatan bioetanol. Salah satu cara pembuatan maltosa adalah hidrolisis pati sehingga terjadi proses pemutusan ikatan 1,4 glikosidik (Aiyer, 2005).

Hidrolisis pati secara tradisional dilakukan dengan menggunakan reaktor tetap dengan penambahan enzim murni, dimana enzim hanya dapat digunakan sebanyak satu kali saja. Hal ini menyebabkan proses dengan menggunakan teknik tersebut memiliki produktivitas rendah karena membutuhkan waktu reaksi yang lama, berkisar antara 24 hingga 48 jam. Selain itu proses tersebut juga memerlukan reaktor yang besar karena setiap proses produksi menggunakan volume larutan yang banyak (Paolucci et al. 1999) 
Salah satu metode alternatif yang bisa menggantikan metode reaktor tetap adalah dengan menggunakan reaktor membran ultrafiltrasi. Dengan metode ini maka produk hidrolisis yang memiliki ukuran lebih kecil dipisahkan dari larutan induknya, sedangkan enzim yang memiliki ukuran besar akan terus digunakan sebagai katalis. Keuntungan lain dari penggunaan metode ini adalah inhibitor yang memiliki ukuran kecil akan dikeluarkan dari reaktor sehingga kecepatan reaksi hidrolisis akan konstan, sedangkan kelemahan metode ini adalah adanya penurunan nilai fluks akibat adanya efek fouling saat berlangsung nya reaksi (Grzeoekowiak and Slomiska, 2005; Dziezak, 1990; Paolucci et al. 2000).

Ada beberapa jenis membran yang telah digunakan untuk melakukan pemisahan maltosa dari pati seperti membran tabular dan hollow fiber (Miura, 2002), membran dinamis zirconium (Chin and Chiang, 1999 dan membran polyetilen (Sanguanruksa and Rujiravanit, 2004). Masingmasing membran tersebut memiliki selektivitas yang berbeda terhadap campuran maltosa dan pati.

Pada penelitian ini dibuat membran campuran antara Polimetilmetakrilat (PMMA) dan bentonit. Pemilihan PMMA dan bentonit sebagai bahan pembuat membran karena PMMA adalah suatu polimer yang telah banyak digunakan untuk membuat membran (Veluru et al, 2007). Selain itu, PMMA juga pernah digunakan sebagai bahan dasar pembuatan komposit dengan mencampurkan senyawa tersebut dengan karbon nanotube (Kim 2008; Sundaray et al. 2008) dan juga padatan imogolit (Yamamoto 2005).

Keunggulan PMMA adalah kemampuannya untuk bercampur dengan senyawa lain untuk membentuk suatu membran seperti dengan polivinil asetat (PVA) (Lee et al, 2002), divinilbenzen (Aungsupravate et al, 2007), tetraetilortosilikat (TEOS) (Zulfikar et al, 2007), Polisiloksan (XU et al, 2015), Poliviviliden flourida (Cui et al, 2015) dan polianilin (PANI) (Veluru et al, 2007).

Lebih lanjut, bentonit adalah senyawa yang digunakan untuk meningkatkan kekuatan membran. Beberapa penelitian menunjukkan bahwa bentonit dapat bercampur dengan polimer diantaranya polidieter keton tersulfonasi (Pagidi et al, 2015), polieterimida (Hebbar, 2014) dan asam polikrilat (Bohnhoff and Shackelford, 2013) Membran yang terbentuk diharapkan memiliki selektivitas yang tinggi, fluks yang besar serta memiliki daya tahan terhadap tekanan.
Dari pemaparan di atas maka tujuan dari penelitian ini adalah membuat dan mengkarakterisasi membran PMMA-Bentonit untuk memisahkan maltosa dan pati. Sehingga kita akan dapatkan komposisi PMMA-bentonit yang paling optimum untuk memisahkan pati dari maltose.

\section{BAHAN DAN METODE}

\section{Bahan}

Bahan yang digunakan pada penelitian ini meliputi air demineralisasi (ADM), bentonit, N,Ndimethyl formamide (DMF) Merck, 3,5dinitrosalysilic acid (DNS) Sigma Aldrich, , $\mathrm{I}_{2}$ Merck, KI Sigma Aldrich, , NaOH Sigma Aldrich, NaK tartrat tetrahidrat Merck, soluble starch (pati), polymethylmethacrylate (PMMA) Merck. Instrumen yang digunakan adalah spektrofotometer UV-Vis Spectronic 20 Genesys dan Jeol JSM 6360 LA.

\section{Metode}

Untuk membuat membran, Polymethyl methacrylate PMMA ditimbang sebanyak 2,8 g, kemudian ditambahkan pelarut DMF 17,2 g. Larutan ini kemudian diaduk menggunakan pengaduk magnet selama 12 jam hingga larut sempurna. Larutan ini merupakan larutan PMMA 14\% (m/m). Tambahkan 0,93 gram bentonit ke dalam larutan PMMA 14\% $(\mathrm{m} / \mathrm{m})$, kemudian diaduk sampai seluruh bentonit terdispersi secara merata dalam larutan. Larutan PMMA - bentonit ini kemudian dicetak di atas lembaran kaca, dengan waktu penguapan pelarut 5 menit. Hasil cetakan kemudian dimasukkan ke dalam air sehingga terjadi inversi fase. Membran hasil cetakan kemudian dikeringkan di udara terbuka selama 12 jam.

\section{Karakterisasi Membran}

Karakterisasi yang dilakukan berupa pengamatan penampang membran, pengukuran fluks dan rejeksi membran terhadap pati dan maltosa. Pengamatan penampang membran menggunakan alat Scanning Electron Microscopy (SEM) dengan menggunakan perbesaran 5000 kali.

Pengukuran fluks dilakukan dengan menempatkan lapisan membran dalam sel filtrasi bertekanan 2 bar. Permeat yang keluar ditampung kemudian volume permeat yang keluar ditentukan. Selanjutnya, pati dan maltosa yang terdapat dalam fasa umpan dan permeat ditentukan. Dengan dibandingkan kadar pati dan maltosa di fase umpan dan permeat, dapat ditentukan persen rejeksi membran terhadap pati dan maltosa. 
Persen rejeksi digunakan untuk mengetahui berapa banyak partikel yang tidak bisa dilewatkan oleh membran, atau bisa juga berapa banyak molekul yang ditolak oleh membran sehingga tidak dapat tersaring.

Nilai Fluks dan persen rejeksi dihitung dengan persamaan dibawah ini :

$$
J=\frac{1}{A} \times \frac{d V}{d t}
$$

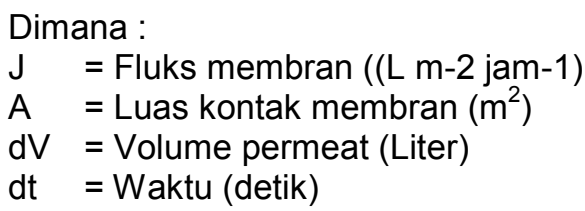

Sedangkan Persen rejeksi di hitung dengan persamaan di bawah ini :

$$
\% R=\frac{C_{R}-C_{P}}{C_{R}} \times 100 \%
$$

Dimana :

$$
\begin{aligned}
& \mathrm{R}=\text { = Persen rejeksi (\%) } \\
& \mathrm{CR}=\text { Konsentrasi zat terlarut dalam larutan } \\
& \text { umpan } \\
& \mathrm{CP}=\text { Konsentrasi zat terlarut dalam } \\
& \text { permeat }
\end{aligned}
$$

\section{Penentuan Kadar Maltosa}

Penentuan kadar maltosa dilakukan menggunakan metode DNS. Standar maltosa yang digunakan adalah 100 ppm, 160 ppm, 200 ppm, 260 ppm, 300 ppm, 360 ppm dan 400 ppm . Sebanyak 0,5 mL larutan standar dicampurkan dengan $0,5 \mathrm{~mL}$ pereaksi DNS dan dipanaskan selama 10 menit pada $100^{\circ} \mathrm{C}$. Sejumlah $150 \mu \mathrm{L}$ sampel diencerkan menjadi $0,5 \mathrm{~mL}$ dan diberi perlakukan yang sama dengan larutan standar. Analisis dilakukan dengan mengukur absorbansi larutan pada $540 \mathrm{~nm}$ menggunakan spektrofotometer UV-Vis (Sumner, 1924).

\section{Penentuan Kadar Pati}

Penentuan pati dilakukan dengan menggunakan metode iodin $\mathrm{I}_{2} / \mathrm{KI}$. Standar pati yang digunakan adalah $6 \mathrm{ppm}, 8 \mathrm{ppm}, 10 \mathrm{ppm}$, 12 ppm, 14 ppm, 16 ppm, 18 ppm dan 20 ppm. Sebanyak $2 \mathrm{~mL}$ larutan standar ini kemudian dicampurkan dengan $1 \mathrm{~mL}$ pereaksi iodin yang telah diencerkan 100 kali dan dilakukan pengukuran absorbansi pada $600 \mathrm{~nm}$ menggunakan spektrofotometer UV-Vis. Sampel diencerkan dengan faktor pengenceran tertentu sampai volume akhir $2 \mathrm{~mL}$ dan diperlakukan sama dengan standar. Pengenceran sampel dilakukan supaya sesuai dengan rentang konsentrasi larutan standar (Bernfeld 1955).

\section{HASIL DAN PEMBAHASAN}

\section{Penampang Membran}

Membran PMMA-Bentonite telah dibuat dengan menggunakan beragam konsentrasi PPMA dan Bentonit. Setidaknya ada 12 komposisi yang berbeda yaitu menggunaan larutan PMMA $10 \%, 13 \%, 14 \%, 15 \%$, dan 16\% persen serta perbandingan antara PMMA: bentonit 1:1, 1:2, 2:1, 2:3, dan 3:1 (Tabel 1).

Dari beragam komposisi tersebut, didapatkan Komposisi membran PMMA-bentonit yang terbaik tercapai pada konsentrasi PMMA $14 \%(\mathrm{~m} / \mathrm{m})$ terhadap pelarut DMF, dengan perbandingan PMMA:bentonit adalah 3:1

Membran yang dibuat dengan mencampurkan PMMA dan bentonit memiliki peningkatan pada ketahanan mekanik dibandingkan dengan membran yang terbuat dari PMMA murni. Membran yang hanya menggunakan PMMA sebagai bahan baku memiliki sifat rapuh dan mudah mengkerut saat dikeringkan di udara terbuka. Namun dengan penambaan bentonit pada membran, sifat rapuh dan pengerutan menjadi menurun.

Pada saat membuat membran dengan komposisi larutan cetak menggunakan PMMA sebesar $13 \%$ atau kurang dari itu, kekuatan mekanik membran yang dihasilkan berkurang, sehingga membran menjadi lebih rapuh dibandingkan membran yang dibuat dari larutan cetak dengan komposisi PMMA 14\%. Hal ini disebabkan oleh jumlah PMMA yang membentuk membran tidak mencukupi untuk membentuk membran yang homogen dengan ketahanan mekanik yang seragam.

Pada membran yang homogen, gaya yang diberikan akan disebar secara merata pada seluruh bagian sehingga membran menjadi lebih stabil. Kestabilan pada membran menjadikan membran tersebut tidak mudah rusak. 
Tabel 1 Hasil cetak membran PMMA-Bentonit

\begin{tabular}{|c|c|c|c|}
\hline No & Bahan Pembuat & Komposisi & Hasil \\
\hline \multirow{2}{*}{1} & PMMA (\%) & 15 & \multirow{2}{*}{ Rusak } \\
\hline & PMMA : Bentonit & $2: 3$ & \\
\hline \multirow[t]{2}{*}{2} & PMMA (\%) & 13 & \multirow[t]{2}{*}{ Rusak } \\
\hline & PMMA : Bentonit & $1: 2$ & \\
\hline \multirow[t]{2}{*}{3} & PMMA (\%) & 13 & \multirow[t]{2}{*}{ Rusak } \\
\hline & PMMA : Bentonit & $3: 1$ & \\
\hline \multirow{2}{*}{4} & PMMA (\%) & 10 & \multirow[t]{2}{*}{ Rusak } \\
\hline & PMMA : Bentonit & $1: 2$ & \\
\hline \multirow[t]{2}{*}{5} & PMMA (\%) & 12 & \multirow{2}{*}{ Rusak } \\
\hline & PMMA : Bentonit & $1: 2$ & \\
\hline \multirow{2}{*}{6} & PMMA (\%) & 16 & \multirow{2}{*}{ Rusak } \\
\hline & PMMA : Bentonit & $2: 3$ & \\
\hline \multirow[t]{2}{*}{7} & PMMA (\%) & 14 & \multirow{2}{*}{ Rusak } \\
\hline & PMMA : Bentonit & $1: 2$ & \\
\hline \multirow{2}{*}{8} & PMMA (\%) & 14 & \multirow{2}{*}{ Rusak } \\
\hline & PMMA : Bentonit & $1: 1$ & \\
\hline \multirow[t]{2}{*}{9} & PMMA (\%) & 14 & \multirow[t]{2}{*}{ Rusak } \\
\hline & PMMA : Bentonit & $2: 1$ & \\
\hline \multirow[t]{2}{*}{10} & PMMA (\%) & 14 & \multirow[t]{2}{*}{ Kurang Baik } \\
\hline & PMMA : Bentonit & $1: 2$ & \\
\hline \multirow[t]{2}{*}{11} & PMMA (\%) & 14 & \multirow[t]{2}{*}{ Kurang Baik } \\
\hline & PMMA : Bentonit & $1: 1$ & \\
\hline \multirow{2}{*}{12} & PMMA (\%) & 14 & \multirow[t]{2}{*}{ Baik } \\
\hline & PMMA : Bentonit & $3: 1$ & \\
\hline
\end{tabular}

Permukaan membran PMMA-bentonit dapat dilihat pada Gambar 1. Pada gambar tersebut teramati tingkat kesulitan pembuatan membran yang ditunjukan oleh warna membran yang tidak seragam, pada bagian kanan warna putih bersih sedangkan di sebelah kiri berwarna cokelat. Hal ini dapat dijelaskan bahwa distribusi bentonit tidak merata, lebih banyak berada di sebelah kiri membran, teramati dari warna dasar bentonit yang cokelat muda. Membran ini dapat digunakan hingga tekanan operasi 2 bar tanpa terjadi robekan. Namun bila membran ini digunakan untuk proses pemisahan dengan tekanan yang lebih dari 2 bar maka membran ini

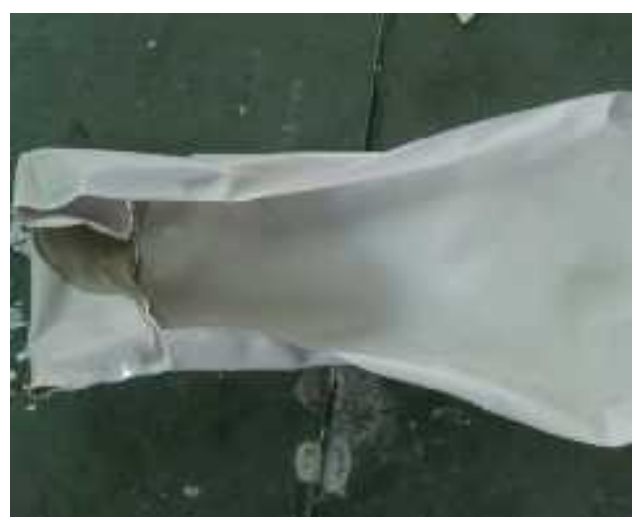

Gambar 1. Membran hasil cetak dapat robek. 
Membran PMMA-bentonit merupakan membran berpori. Hal ini didukung oleh foto SEM penampang melintang membran (Gambar 2) dan foto SEM permukaan membran (Gambar 3). Pada Gambar 2 terlihat penampang melintang dari membran PMMA-Bentonit yang memiliki ketebalan sekitar $50 \mu \mathrm{m}$. Pada Gambar 3 terlihat permukaan membran sangat rapat dengan pori-pori yang kecil menyebar disekitar permukaan membran.

Adanya pori pada membran menjadikan proses pemisahan dapat berlangsung dengan selektif karena molekul yang besar akan tertahan pada lapisan-lapisan yang ada, sedangkan molekul yang lebih kecil akan lolos.

Persebaran bentonit yang tidak merata pada membran mengakibatkan perbedaan pada kekuatan mekanik dari membran. Semakin banyak membran mengandung bentonit, maka kekuatan mekanik membran juga semakin meningkat sehingga tidak mudah sobek. Sedangkan pada membran dengan kandungan bentonit yang sedikit menyebabkan kemungkinan membran robek semakin

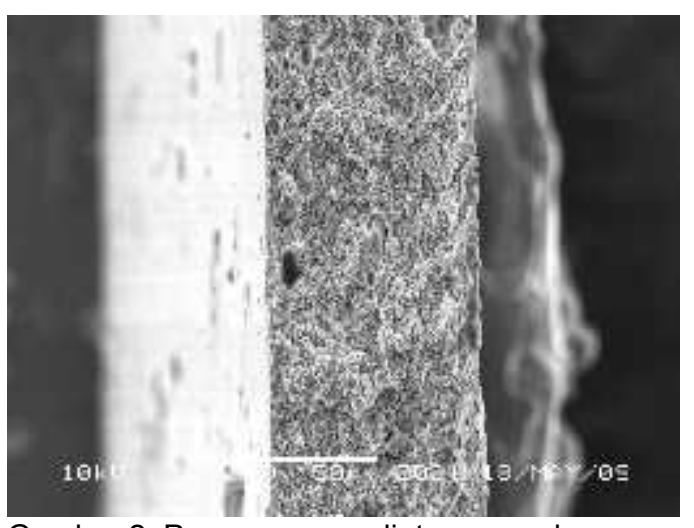

Gambar 2. Penampang melintang membra PMMA-Bentonit (perbesaran 5000x)

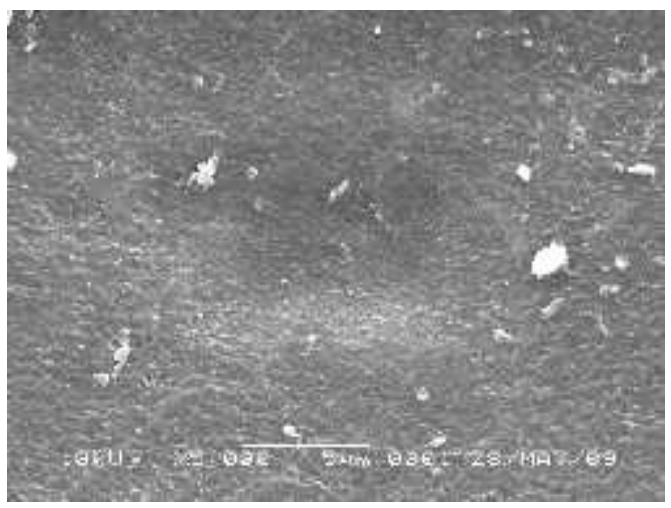

Gambar 3. Permukaan membran PMMA-Bentonit (perbesaran 5000x) meningkat. Perbedaan distribusi bentonit juga berakibat pada pembentukan pori yang tidak seragam, yang terlihat dari fluks membran (Tabel 2) dan perbedaan kemampuan rejeksi membran terhadap pati dan maltosa (Tabel 3 ).

\section{Nilai Fluks}

Tabel 2 menunjukkan bahwa nilai fluks yang dihasilkan oleh membran sangat bervariasi, untuk air demineralisasi berkisar antara 3.36 hingga $7.31 \quad\left(\mathrm{~L}^{-2} \mathrm{jam}^{-1}\right)$. Perbedaan ini disebabkan karena jumlah dan besar nya pori tidak sama antara membran hasil pencetakan.Untuk larutan campuran maltosapati memiliki nilai fluks berkisar antara 0.71 hingga $1.34\left(\mathrm{~L} \mathrm{~m}^{-2} \mathrm{jam}^{-1}\right)$, lebih kecil dibandingkan dengan fluks air demineralisasi. Hal ini dikarenakan terjadinya penyumbatan beberapa pori membran oleh maltosa dan pati (efek fouling), dimana molekul yang akan dipisahkan menyumbat pori-pori membran sehingga nilai fluks menjadi mengecil.

Dalam melakukan proses pemisahan suatu zat dengan menggunakan membran yang berdasarkan pada perbedaan ukuran pori, dapat terjadi melalui dua mekanisme yaitu melalui permukaan membran dan melalui bagian dalam membran. Hal ini dapat dilihat pada gambar 4 .

Pada proses pemisahan melalui permukaan membran (mekanisme A), permukaan membran memiliki ukuran pori yang lebih besar dibandingkan dengan bagian dalam membran tersebut. Hal ini mengakibatkan molekul yang memiliki ukuran lebih besar dibandingkan dengan ukuran pori permukaan tidak bisa berpermeasi melalui membran. Mekanisme ini biasanya terjadi pada pemisahan dengan menggunakan teknik ultrafiltrasi (Cooke 2002).

Tabel 2. Nilai fluks membran terhadap Air Demineralisasi (ADM) dan campuran maltosa-pati

\begin{tabular}{ccc}
\hline \multirow{2}{*}{ Replika } & \multicolumn{2}{c}{ Fluks $\left(\mathrm{L} \mathrm{m}^{-2} \mathrm{jam}^{-1}\right)$} \\
\cline { 2 - 3 } & ADM & Campuran \\
\hline 1 & 5.01 & 1.18 \\
2 & 3.36 & 1.34 \\
3 & 5.54 & 1.65 \\
4 & 7.31 & 0.71 \\
5 & 4.01 & 0.94 \\
\hline Rata-rata & 5.05 & 1.16 \\
\hline
\end{tabular}


A

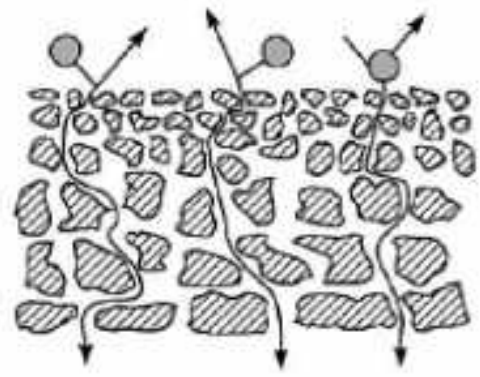

19

B

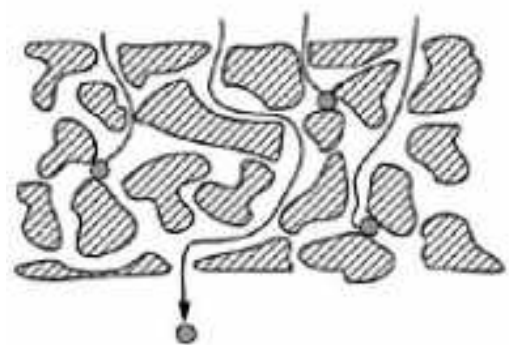

Gambar 4. Mekanisme pemisahan membran (A) melalui permukaan membran (B) melalui bagian dalam membran (Cooke, 2002)

Lebih jauh Cooke (2002) menjelaskan tentang pemisahan dengan menggunakan mekanisme B, hampir seluruh molekul dapat berpermeasi ke dalam membran namun hanya sebagian saja yang dapat melewatinya. Mekanisme pemisahan terjadi berdasarkan pada kemampuan molekul tersebut dalam melewati pori bagian dalam dari membran. Mekanisme B ini biasanya terjadi pada membran yang digunakan untuk melakukan pemisahan dengan menggunakan teknik mikrofiltrasi.

Berdasarkan dari mekanisme yang terjadi, proses pemisahan pati-maltose dengan menggunakan membran PMMA-bentonin ini mengikuti mekanisme $B$ yaitu pemisahan melalui bagian dalam membran (Cooke, 2002).

\section{Persen Rejeksi}

Pada proses pemisahan antara maltosa dan pati, membran haruslah selektif terhadap molekul pati, namun disisi lain membran juga harus mampu melewatkan maltosa. Hal ini dapat ditunjukkan dari nilai persen rejeksi pati yang tinggi dan nilai persen rejeksi terhadap maltosa yang harus semakin kecil. Dengan kriteria membran seperti itu maka molekul maltosa dapat dipisahkan dari pati.
Tabel 3. Nilai persen rejeksi membran terhadap maltosa dan pati

\begin{tabular}{ccc}
\hline \multirow{2}{*}{ Replika } & \multicolumn{2}{c}{ Rejeksi (\%) } \\
\cline { 2 - 3 } & Pati & Maltosa \\
\hline 1 & 40.10 & 1.88 \\
2 & 45.05 & 4.70 \\
3 & 69.35 & 3.03 \\
4 & 55.48 & 0.00 \\
5 & 68.60 & 4.72 \\
\hline Rata-rata & 55.72 & 2.87
\end{tabular}

Data yang diperoleh dari penelitian memperlihatkan bahwa membran sudah cukup baik untuk memisahkan antara pati dan maltose. Hal tersebut seperti tercantum pada tabel 2, dimana nilai persen rejeksi untuk maltosa dan pati sangat bervariasi, untuk pati berkisar antara 40,10 hingga $69,35 \%$ sedangkan untuk maltosa antara 0 hingga $4,72 \%$.

Persen rejeksi yang kecil terhadap maltosa dan besar terhadap pati menunjukkan bahwa pori-pori membran yang terbentuk lebih besar dari pada ukuran maltosa dan lebih kecil dibandingkan dengan pati. Sehingga membran mampu memisahkan molekul maltosa dari pati dengan cukup baik. Molekul Maltosa yang berukuran lebih kecil akan melewati membran sedangkan molekul pati yang berukuran lebih besar akan lebih banyak tertahan/tertolak oleh membran.

\section{KESIMPULAN}

Pada penelitian ini telah berhasil dibuat membran PMMA-Bentonit dengan komposisi terbaik yaitu konsentrasi PMMA $14 \%(\mathrm{~m} / \mathrm{m})$ terhadap pelarut $\mathrm{N}, \mathrm{N}$-dimetilformamida, dan perbandingan antara PMMA:Bentonit adalah 3:1. Nilai rata-rata fluks untuk larutan campuran maltosa-pati adalah $1,16 \mathrm{~L} \mathrm{~m}^{-2} \mathrm{jam}^{-1}$. Membran yang dibuat mampu memisahkan maltosa dari pati dengan nilai rejeksi rata-rata terhadap pati adalah $55,72 \%$ sedangkan terhadap maltosa adalah $2,87 \%$. Data rejeksi menunjukkan membran PMMA-bentonit memiliki potensi untuk pemisahan pati dan maltosa. Optimasi diperlukan untuk pembuatan membran yang memiliki penyebaran bentonit yang merata. 


\section{SARAN}

Pembuatan membran yang digunakan untuk memisahkan maltosa dan pati sudah dapat dilakukan secara skala laboratorium dengan hasil yang baik. Oleh karena itu maka ke depannya perlu dilakukan riset lebih lanjut dengan menggunakan membran dan reaktor yang memiliki ukuran lebih besar. Hal ini untuk melihat kinerja membran pada volume produksi yang mendekati skala ekonomi.

\section{DAFTAR PUSTAKA}

Aiyer, P.V. 2005. Amylases and their applications. African journal of biotechnology 4 (13) : 1525-1529.

Aungsupravate, O., W. Kangwansupamonkon, W. Chavasiri, and S. Kiatkamjornwong. 2007. Synthesis and properties of solvent absorptive methyl methacrylate-divinyl benzene copolymer beads. Journal of polymer engineering and science 47 (4) : 447459.

Bernfeld, P. 1955. Amylases, $\alpha$ and $\beta$, Methods in Enzymology, 1, 149-158

Bohnhoff, G.L., and C.D. Shackelford. 2013. Improving membrane performance via bentonite polymer nanocomposite. Journal applied clay science $86: 83-98$

Cooke, M. 2002. Encyclopedia in Separation Science. Academic Press.

Chin Jen Tien, Been Huang Chiang. 1999. Immobilization of a-amylase on a zirconium dynamic membrane. Journal of process biochemistry 35 (3) : 377383.

Cui, W-w., D-y. Tang, and Z-I Gong. 2015. Electrospun poly(vinylidene flouride)/poly(methyl methacrylate) grafted $\mathrm{TiO}_{2}$ composite nanofibroues membrane as polymer electrolyte for lithium-ion batteries. Journal of power sources 223 : 206-213.

Dziezak. J.D. 1990. Membran Separation Technology Offers Processors Unlimited Potential. Journal of food technology 44 (9) : 108-113.

Grzeoekowiak-Przywecka. A and L. Slominska. 2005. Continuous potato starch hydrolysis process in a membran reactor with tubular and hollow-fiber membran. Desalination 184 (1-3) : 105-112.

Hebbar, R.S., A.M. Ismail, and A.F. Ismail. 2014. Preparation and evaluation of heavy metal rejection properties of polyetherimide/porous activated bentonite clay nanocomposite membrane. RSC Advance 4 : 4724047248.

Kim, K. H. and W. H. Jo. 2008. Improvement of tensile properties of poly(methyl methacrylate) by dispersing multiwalled carbon nanotubes functionalized with poly(3hexylthiophene)-graft-poly(methyl thacrylate). Journal of composites science and technology 68 : 21202124.

Lee, W. K., Ryou, J. H., Cho, W. J., Ha, C. S., and H. Nakaharaa. 2002. Miscibility of poly(methyl methacrylate)-/poly(vinyl acetate) blend in 2-dimensional state at the air/water interface. Journal of molecular crystals and liquid crystals 377 (1) : 337-340.

Miura, S. 2002. High-throughput hydrolysis of starch during permeation across aamylase- immobilized porous hollowfiber membranes. Journal of radiation physics and chemistry 63 : 143-149.

Pagidi, A., Y.L. Thuyavan, G. Arthanareeswaran, A.F. Ismail, J. Jaafar, and D. Paul. 2015. Polumeric membrane modification using SPEEK and bentonite for ultragiltration of dairy wastewater. Journal of applied polymer science $132: 41651$

Paolucci-Jeanjean. D., M.P. Belleville, G.M. Rios and N. Zakhia. 1999. Why on earth can peopleneed continuous recycle membran reactors for starch hydrolysis. Journal of Starch 51 (1) : 25-32.

Paolucci-J. D., M.P. Belleville, G.M. Rios, and N. Zakhia. 2000. The effect of enzyme concentration and space time on the performance of a continuous recycle membrane reactor for one-step starch hydrolysis. Journal of biochemical engineering $5: 17-22$.

Sumner, J. 1924. The estimation of sugar in diabetic urine, using dinitrosalicylic acid. Journal of biological chemistry 62 : 287-290.

Sundaray, B., J. Babu, V. Subramanian, and S. T. Natarajan. 2008. Preparation and Characterization of Electrospun Fibers of Poly(methyl methacrylate) - Single Walled Carbon Nanotube Nanocomposites. Journal of engineered fibers and fabrics 3 (4) : 39-45. 
Sa-nguanruksa, J, and R. Rujiravanit. 2004. Porous polyethylene membrans by template-leaching technique: preparation and characterization. Journal of polymer testing 23 : 91-99.

Veluru, J. B., K.K. Satheesh, D.C. Trivedi, M.V. Ramakrishna, and N.T. Srinivasan. 2007. Electrical Properties of Electrospun Fibers of PANI-PMMA Composites. Journal of engineered fibers and fabrics 2 (2) : 25-31.

$\mathrm{Xu}$, J-k., W-y.Zhu, L-I. Zhang, and Y-c Zhang. Preparation and characterization of transparent and foldable polysilovabepoly)methyl methacrylate) membrane with a high refractive index. Journal of applied polymer science $132: 41651$.

Yamamoto, K., H. Otsuka, S. I. Wada, D. Sohn, and A. Takahara. 2005. Preparation and properties of [poly(methyl methacrylate)/imogolite] hybrid via surface modification using phosphoric acid ester. Journal of Polymer 46 (12) : 12386-12392.

Zulfikar, M. A., A.W. Mohammad, A. A. Kadhum, and N. Hilal. 2007. Synthesis and characterization poly(methylmethacrylate) $/ \mathrm{SiO}_{2}$ hybrid membran. Journal of materials science and engineering a 452 : 422-426. 